\title{
Effect of Periodic Training to Improve the Speed of 110-meter Hurdles "Experimental Research on University Level Player at Punjab Pakistan"
}

\author{
Usman Muavua ${ }^{1}$, Salahuddin Khan ${ }^{2}$, Adnan Ahmad ${ }^{1}$, Asia Bano ${ }^{1}$, Bilal Mustafa ${ }^{3}$, Khalida Saleem ${ }^{4}$ \\ ${ }^{1}$ Department of Sports Sciences, Riphah International University, Faisalabad, Pakistan \\ ${ }^{2}$ Department of Sports Sciences, Gomal University, Dera Ismail Khan, Pakistan \\ ${ }^{3}$ Danish School, Bahawalpur, Pakistan \\ ${ }^{4}$ Punjab College, Arifwala, Pakistan
}

Email address:

Usman.muavia121@gmail.com (U. Muavua)

${ }^{*}$ Corresponding author

\section{To cite this article:}

Usman Muavua, Salahuddin Khan, Adnan Ahmad, Asia Bano, Bilal Mustafa, Khalida Saleem. Effect of Periodic Training to Improve the Speed of 110-meter Hurdles "Experimental Research on University Level Player at Punjab Pakistan". International Journal of Science, Technology and Society. Vol. 9, No. 5, 2021, pp. 234-238. doi: 10.11648/j.ijsts.20210905.15

Received: May 12, 2021; Accepted: July 12, 2021; Published: October 28, 2021

\begin{abstract}
As a element of a dynamic event, ten hurdles of 1.067 meters in height are equally divided along a straight path of 110 meters. For the $110 \mathrm{~m}$ hurdles, the leading hurdle is set after a run-up of 13.72 meters from the beginning line. The following nine obstacles are set a good ways off of 9.14 meters from one another, and the final lap from the last obstacle to the end goal is 14.02 meters. The important point of the exploration study was to foster all the actual part of the player of $110 \mathrm{~m}$ hurdle since it's a difficult race event for this event a player have need a full fit body there are numerous capable parts in Pakistan however they have not treat with great coaching. To satisfy their need the expert have proceed with this investigation to present another preparation convention that will assist the hurdlers with fostering their ability, speed, and strength. Objective: To introduce advance scientific training techniques and coaching, to introduce periodzied training program for $110 \mathrm{~m}$ hurdle players. To explore effective training workout for 110 meter hurdles. Motivation behind the examination: The reason for this examination study was to evaluate the preparation of competitors and furthermore present new plans with the assistance of periodization. Philosophy: Test Strategy is intended to use for this exploration. Pretest and posttest were taken to analyze competitor's presentation. Finish of the examination: Pretest was taken to executing progress of player. And afterward researcher was applied planned training plan on them, to work on the speed in the hurdles following to carrying out the training plan. Specialist will set a Posttest to check the believability of training plans it has impact on the competitors analyst will discovered huge upgrades in competitors timing its aim to work on the speed of the competitor in hurdles and performance. So should follow the training plan due to the methodology the various phases of the preparation plan get bit by bit. Normal preparing a few outcomes. After examination the analyst recognize that this exploration depends on actual exercise for 110 meter hurdler. The significant factor in 110 meter obstacles is speed, step length, step recurrence and force/strength for achieving these significant variables of 110 meter obstacles were follow the training plan and exercises. Adequacy of this arrangement shows brings about the post test.
\end{abstract}

Keywords: Improvement, Speed, Periodic Training

\section{Introduction of the Study}

110-meter obstacles, is a jumping track occasion for men. As a component of a dashing occasion, ten obstacles of 1.067 meters ( $3.5 \mathrm{ft}$ or 42 inches) in tallness are uniformly divided along a straight course of 110 meters [1]. For the $110 \mathrm{~m}$ hurdles, the first hurdle is placed after a run-up of 13.72 meters $(45 \mathrm{ft})$ from the starting line. The next nine hurdles are 
set at a distance of 9.14 meters $(30 \mathrm{ft})$ from each other, and the home stretch from the last hurdle to the finish line is 14.02 meters (46 ft) long [2]. The basic aim of the research study will to develop all the physical component of the player of $110 \mathrm{~m}$ hurdle because it's a very difficult race event for this event a player have tneed a full fit body there are many talented players in Pakistan but they have not treat with good coaching [3]. To fulfill their need the researcher will continue this study to introduce a new training protocol that will help the hurdlers to develop their skill, speed, agility and strength [4].

Objectives:

To introduce advance scientific training techniques and coaching.

To introduce periodzied training program for $110 \mathrm{~m}$ hurdle players.

To explore effective training workout for 110 meter hurdles.

\section{Literature Review}

The principal guidelines were endeavored in 1864 in Oxford and Cambridge: The length of the course was set to 120 yards $(109.7 \mathrm{~m})$ and over its course, sprinters were needed to clear ten 3 foot 6 inch $(1.07 \mathrm{~m})$ high obstacles. The stature and dividing of the obstacles have been identified with Magnificent units from that point onward. After the length of the course was gathered together to 110 meters in France in 1888 , the principles were practically finished (aside from Germany where 1 meter high obstacles were utilized until 1907 [5].

The greatly developed obstacles of the good 'ol days were first supplanted in 1895 with fairly lighter T-formed obstacles that sprinters had the option to push over. Nonetheless, until 1935 sprinters were precluded in the event that they thumped down multiple obstacles, and records were possibly perceived if the sprinter had left all obstacles standing. In 1935 the T-molded obstacles were supplanted by L-formed ones that effectively fall forward whenever caught and consequently lessen the danger of injury. Be that as it may those obstacles are weighted so it is disadvantageous to hit them [6].

The current running style where the first hurdle is taken on the run with the upper body lowered instead of being jumped over and with three steps each between the hurdles was first used by the 1900 Olympic champion, Alvin Kraenzlein [7].

The 110 meter hurdles have been an Olympic discipline since 1896. Women ran it occasionally in the 1920 s but it never became generally accepted. From 1926 on, women have only run the 80 meter hurdles which was increased to 100 meters starting in 1961 on a trial basis and in 1969 in official competition [8].

In 1900 and 1904, the Olympics also included a 200 meter hurdles race, and the IAAF recognized world records for the 200 meter hurdles until 1960 (Matthews \& Marshall, 2003). Don Styron held the world record in the event for over 50 years until Andy Turner broke the record in a specially arranged race at the Manchester City Games in 2010. Styron still holds the world record in the 220 yard low hurdles [6].

\subsection{Periodization}

"Is a plan for conditioning based on manipulation of volume or intensity of physical activity over a period of time" The goal of periodization is to plan in advance to achieve peak performance at specific time without over training or injury. Periodzied model produce statically superior results in a variety of performance measures (strength, power and endurance.

\subsubsection{Periodization}

Off season/ preparatory phase

Pre-season/pre- season + in season called competitive phase In-season/in-season + pre- season called competitive phase Post season/ transition phase

\subsubsection{Periodization Cycle \\ MICRO cycle \\ 1 week \\ Or up to 4 weeks \\ MESO cycle}

Several weeks

Several months (2-6)

MACRO cycle

Training year

Months

4 year

Subsequent to making conference with public level mentors, scientist will planned meso pattern of actual exercise for first class competitor of 110 meter obstacles. This arrangement has significant spotlight on to work on the circumstance of competitors which prompts accomplishment in various rivalries and levels.

\subsubsection{Pyramid}

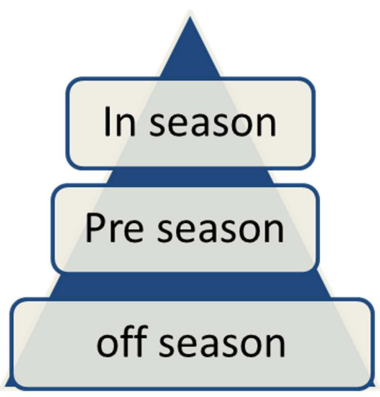

Figure 1. Showing the seasons plans.

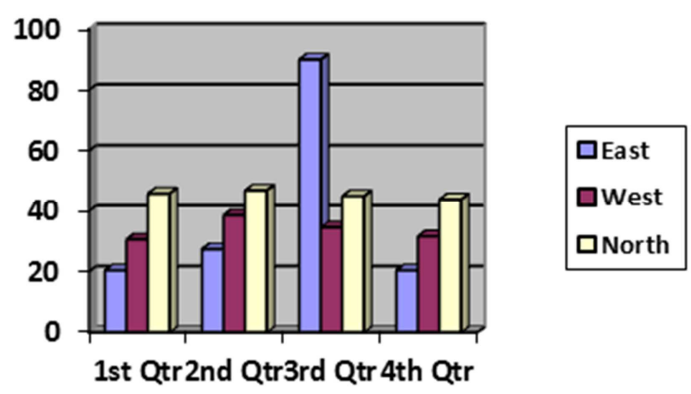

Figure 2. Showing the volume and intensity of the plan. 


\subsection{Sprint Hurdling Technique}

\subsubsection{The Start and Approach}

In sprint hurdling the first hurdle is only some seven or eight strides away so the athlete must come upright at the $3 \mathrm{rd}$ or 4 th stride, much earlier than the sprinter. To enable this to happen the block spacing will have to be slightly altered [9]. When using an eight stride approach the take-off foot is placed in the front block [10].

\subsubsection{Hurdle Clearance}

The athlete must attack the hurdle and aim to clear it, by approx. 17 to $18 \mathrm{~cm}$, as quickly and efficiently as possible, raising their center of gravity only a little more than in a normal sprint action [11].

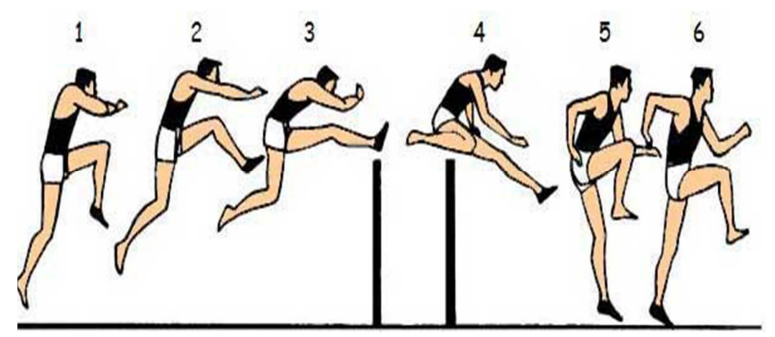

Figure 3. Showing the crossing style.

\subsubsection{Leg Action}

The last stride of the approach to the first hurdle is shortened in order to allow the take-off leg to move rapidly under the hips. This ensures that a fast effective drive can be made across the hurdle. The take off distance is 1.98 meters to 2.29 meters $\left(6 \frac{1}{2}\right.$ to $71 / 2$ feet) from the hurdle. The body's center of gravity is ahead of the foot on takeoff [12].

\subsubsection{Action of the Leading Leg}

1) The knee must be picked up fast.

2) The knee is driven at the hurdle.

3) The lower part of the leg is left low and extends once the knee reaches the height of the barrier.

4) The knee must be picked up in line with the vertical center line of the body.

5) There should be no tendency for the knee to be pulled across the body or for the lower leg to go out and round.

6) The foot of the lead leg reaches its highest point some 15 to 30 centimeters ( 6 to 8 inches) in front of the hurdle rail.

7) As the heel of the lead leg passes the barrier it must be pulled down and back to land under the body.

8) There is no necessity for the lead leg to be straight over the top of the hurdle.

9) The leg straightens as it descends towards the ground.

10)The foot of the lead leg grounds at 114 to 137 centimeters ( $3 \frac{3}{4}$ to $4 \frac{1}{2}$ feet) beyond the hurdle [1].

\subsubsection{Action of the Trailing Leg}

1) The trailing leg drives the body at the hurdle as the lead leg rises.

2) The recovery of the trail leg must begin from well behind the body if the drive is to be completed.
3) The athlete should feel the trailing knee sweeping wide and flat over the hurdle.

4) As the leg crosses the hurdle, the foot must be cocked at the ankle so that the foot does not hit the barrier.

5) After crossing the barrier, the knee continues to rise and comes round in front of the body.

Many young athletes have a tendency to drop the trail leg off to the side after it has crossed the barrier. This has the effect of making the first stride short and pulling the athlete off balance. The trail leg must be pulled through high and fast so that the first stride is fast [13].

\subsubsection{Arm Action}

As in sprinting, the arms act to balance the body and counter the rotations produced by the legs. The arm opposite to the lead leg actually leads the action into the hurdle and pushes/dives forwards as the lead leg rises. The other arm should be taken back in a normal sprinting action. As the trail leg comes round the leading arm swings back and wide to counter the rotation of the trail leg $[10,11]$.

\subsubsection{Running Between Hurdles}

Three strides are used to cover the ground between the hurdles. To achieve this, the athlete has to modify his sprinting technique to make it fit the gap. A fast leg cadence and a shorter stride length are needed [14].

\subsubsection{Safety}

Hurdling is dangerous on wet grass or any other slippery surface. It is also dangerous for children to run over hurdles in the opposite way to the correct running direction (i.e. with the feet of the hurdles on the far side). It is important to help the athletes in the learning situation, by using adapted equipment, lowering the hurdles and altering the distance between hurdles [15].

\section{Methodology}

Experimental Methodology is designed to use for this research. Pretest and posttest were taken to examine athlete's performance. Our main focus of this project was to design a plan for the athletes that will help them to improve their speed and timings in hurdles which is good for athletes..

\subsection{Limitations of the Project}

The project between the ages of 20-25 years male university student's hurdlers.

\subsection{Specification of the Research}

This research was under taken to evaluate a physical training program for high performance in hurdles. It is remarkable research is being done in Pakistan. Which is done with the assistance of coaches, physical education teacher, athlete and students of the Sports Sciences? This research will provide specifically designed hurdle race. Furthermore the core emphasis of this research is to provide latest scientific and periodic training programs regarding high performance in national and international competitions. 


\subsection{The Following Training Plan Has Been Divided in to Three Phases}

Off Season 5 weeks
Pre-season 3 weeks

In season 2 week

Note; warm up and cool down both are necessary.

Table 1. Showing the intensity and volume of the training.

\begin{tabular}{llll}
\hline $\begin{array}{l}\text { Off season preparatory } \\
\text { phase }\end{array}$ & Pre-season & In- season & Competition \\
\hline Conditioning & Specific strength endurance, & start Technique and maintain & Transition phase \\
General endurance, & speed endurance, and speed & pure speed, 90 to $95 \%$ & After the final contest, \\
strength endurance with short & drills according to the event & accelerate with long recovery & provides Active rest, \\
recovery & With medium recovery & $30 \%$ volume and $70 \%$ & Competition days \\
$70 \%$ volume and $30 \%$ & $60 \%$ volume and & intensity mean $30 \%$ health & low-intensity, low-volume \\
intensity & $40 \%$ intensity mean & related and $70 \%$ skill related & \\
Mean $70 \%$ health related & $60 \%$ health related and $40 \%$ & fitness & \\
And $30 \%$ skill related fitness & skill related fitness & &
\end{tabular}

\subsection{Training Plan}

Table 2. Showing the training plan.

\begin{tabular}{|c|c|c|c|c|c|}
\hline Monday & Tuesday & Wednesday & Thursday & Friday & Saturday \\
\hline $\begin{array}{l}1^{\text {st }} \text { week plan } \\
20-25 \\
\text { Running and stretching } \\
\text { coordination } \\
\text { Exercise cool down }\end{array}$ & $\begin{array}{l}\text { Weight training } \\
\text { Full body } \\
\text { Lunges + hurdle } \\
\text { jump }\end{array}$ & $\begin{array}{l}12 \text { hurdles *8 raps } \\
\text { Low height and short } \\
\text { distance }\end{array}$ & $\begin{array}{l}\text { Weight training full } \\
\text { body after it striding, } \\
\text { hopping lunges }\end{array}$ & $\begin{array}{l}\text { All hurdles drills }+ \\
3 * 200 \mathrm{~m}\end{array}$ & $\begin{array}{l}\text { Weight training full body } \\
\text { after it general specific } \\
\text { exercises cool down }\end{array}$ \\
\hline \multicolumn{6}{|l|}{$2^{\text {nd }}$ week plan } \\
\hline $\begin{array}{l}\text { Monday } \\
\text { Fartlek training } \\
20-25 \text { mint } \\
\text { Up to } 400 \text { meter }\end{array}$ & $\begin{array}{l}\text { Tuesday } \\
\text { Weight training } \\
\text { upper body }\end{array}$ & $\begin{array}{l}\text { Wednesday } \\
10 \text { hurdles } 8 \text { raps low } \\
\text { height and short distance }\end{array}$ & $\begin{array}{l}\text { Thursday } \\
\text { Weight training } \\
\text { lower body }\end{array}$ & $\begin{array}{l}\text { Friday } \\
2 \times 150 \mathrm{~m} \\
2 \times 200 \mathrm{~m} \\
1 \times 300 \mathrm{~m}\end{array}$ & $\begin{array}{l}\text { Saturday } \\
\text { Up Hill \& downhill } \\
\text { Resistance Training }\end{array}$ \\
\hline \multicolumn{6}{|l|}{$3^{\text {rd }}$ week plan } \\
\hline $\begin{array}{l}\text { Fartalik training up to } 400 \\
\text { meter }\end{array}$ & $\begin{array}{l}\text { Weight training } \\
\text { after it hurdles } \\
\text { jump and walk } \\
\text { over }\end{array}$ & $\begin{array}{l}\text { Hurdles speed endurance } \\
4 * 10 \text { hurdles. } \\
\text { Low height short } \\
\text { distance after it } \\
1 \times 100 \mathrm{~m} \\
1 \times 200 \mathrm{~m}\end{array}$ & $\begin{array}{l}20-25 \mathrm{~m} \text { jogging }+ \\
\text { core stability }\end{array}$ & $\begin{array}{l}\text { Speed endurance } \\
8 * 200 \mathrm{~m}\end{array}$ & $\begin{array}{l}\text { Weight training after if } \\
\text { hurdle walk over }\end{array}$ \\
\hline \multicolumn{6}{|l|}{$4^{\text {th }}$ week plan } \\
\hline $\begin{array}{l}\text { Speed endurance training } \\
8 * 150 \mathrm{~m}\end{array}$ & $\begin{array}{l}\text { Weight training } \\
\text { full body }\end{array}$ & $\begin{array}{l}\text { Speed hurdles training } \\
\text { hurdles } \\
3 \text { raps * } \\
3 \text { hurdles } 3 \text { raps* } \\
\text { 5hurdles } 2 \text { raps* } \\
1 \text { hurdle } 1 \text { rap* } 10 \text { hurdles } \\
* 10 \text { raps } \\
\text { Low height and short } \\
\text { distance }\end{array}$ & $\begin{array}{l}10-15 \text { mint jogging } \\
\text { and core stability }\end{array}$ & $\begin{array}{l}\text { Short speed work } \\
3 \times 30 \mathrm{~m} \\
2 \times 60 \mathrm{~m} \\
2 \times 80 \mathrm{~m} \\
1 \times 100 \mathrm{~m} \\
1 \times 150 \mathrm{~m} \\
70 \% \text { to } \\
80 \% \text { intensity }\end{array}$ & $\begin{array}{l}\text { Weight training full body } \\
+ \\
\text { All hurdles drills }\end{array}$ \\
\hline $\begin{array}{l}5^{\text {th }} \text { week plan } \\
\text { Hurdles speed work with } \\
\text { standing start intensity } 70 \\
\text { to } 80 \text { percent } \\
1 \text { hurdle } \times 3 \text { rap } \\
3 \mathrm{~h} \times 2 \text { rap } \\
5 \mathrm{~h} \times 1 \text { rap } \\
\text { Full height and full distance } \\
2 \times 120 \mathrm{~m} \\
6^{\text {th }} \text { week plan }\end{array}$ & $\begin{array}{l}\text { Full body Weight } \\
\text { training } \\
+ \\
\text { Strides }\end{array}$ & $\begin{array}{l}\text { Short speed work } \\
3 \times 30 \mathrm{~m} \\
2 \times 60 \mathrm{~m} \\
2 \times 80 \mathrm{~m} \\
1 \times 100 \mathrm{~m} \\
1 \times 150 \mathrm{~m} \\
70 \% \text { to } 80 \% \text { intensity }\end{array}$ & $\begin{array}{l}15 \text { mint jogging } \\
+ \\
\text { Core stability }\end{array}$ & $\begin{array}{l}\text { Weight training full } \\
\text { body } \\
+ \\
\text { Strides }\end{array}$ & $\begin{array}{l}\text { Hurdles speed work with } \\
\text { starting blocks } \\
1 \mathrm{~h} \times 3 \mathrm{rap} \\
3 \mathrm{~h} \times 2 \mathrm{rap} \\
5 \mathrm{~h} \times 1 \mathrm{rap} \\
7 \mathrm{~h} \times 1 \mathrm{rap} \\
110 \mathrm{~h} \times 1 \mathrm{rap} \\
\text { Full height full distance }\end{array}$ \\
\hline $\begin{array}{l}110 \mathrm{~m} \text { hurdles with starting } \\
\text { blocks with timing } \\
\text { Intensity } 80-90 \%\end{array}$ & $\begin{array}{l}\text { Jogging } 15 \mathrm{~m} \\
+ \\
\text { Coordination } \\
\text { exercise } \\
+ \\
\text { Core stability }\end{array}$ & $\begin{array}{l}\text { Short speed work } \\
3 \times 30 \mathrm{~m} \\
2 \times 60 \mathrm{~m} \\
2 \times 80 \mathrm{~m} \\
1 \times 100 \mathrm{~m} \\
1 \times 150 \mathrm{~m} \\
80 \% \text { to } 90 \% \text { intensity }\end{array}$ & $\begin{array}{l}\text { Light weight training } \\
+ \\
\text { Hurdles walk over }\end{array}$ & $\begin{array}{l}15 \text { min jogging } \\
+ \\
\text { Strides }\end{array}$ & $\begin{array}{l}1 \text { hurdle start } 3 \text { times } \\
+ \\
3 \text { hurdles start } 2 \text { times } \\
\text { Intensity } 90 \%\end{array}$ \\
\hline
\end{tabular}




\section{Findings}

Pretest was taken to implementing the periodic training plan. And then researcher applied designed periodic training plan on them, to improve the speed in the hurdles after implementing the periodic training plan. Researcher will set a Posttest to check the credibility of periodic training plans it has effect on the athletes researcher will found tremendous improvements in athletes timing its mean to improve the speed of the athlete in hurdles and performance. So must follow the periodic training plan because of the approach the different stages of the training plan wget step by step. Regular training also have some results.

\subsection{Conclusion}

This research is based on periodic physical workout for 110 meter hurdler. The important factor in 110 meter hurdles is speed, stride length, stride frequency and power/strength for attaining these important factors of 110 meter hurdles were follow the periodic training workouts or plans. Effectiveness of this plan shows results in the post test.

\subsection{Recommendation}

1) Must follow periodic training plan.

2) Must follow training principles which help to understand the different progressions of the training.

3) Most of time injuries comes due to without warm up and cool down so train with warm up and cool down.

4) Don't Stop Training, Keep little touch with training when off season.

5) Use Mental Techniques just like imagery elite athletes use imagery before the race to visualize the race to control the arousal and to concentrate on the race.

6) Follow rules and regulations given by IAAF.

7) Don't cheat Avoid drug abuse.

8) Give respect to your team mates and opponent players.

9) Give respect to your followers.

10)Follow different scientific techniques which lead to improve performance.

\section{References}

[1] Carr, G., \& Carr, G. A. (1999). Fundamentals of track and field: Human Kinetics.
[2] Hickey, J. (2006). Understanding athletics: Coachwise $1^{\text {st }} 4$ sport.

[3] Li, J. P., Chen, R., Lee, J., \& Rao, H. R. (2013). A case study of private-public collaboration for humanitarian free and open source disaster management software deployment. Decision Support Systems, 55 (1), 1-11.

[4] Crawley, A. A., Sherman, R. A., Crawley, W. R., \& Cosio-Lima, L. M. (2016). Physical fitness of police academy cadets: Baseline characteristics and changes during a 16-week academy. Journal of strength and conditioning research, 30 (5), 1416.

[5] Lipson, A., Lipson, S. G., \& Lipson, H. (2010). Optical physics. Cambridge University Press.

[6] Blauvelt, G. R. (2006). Machineshop: a design environment for supporting children's construction of mechanical reasoning and spatial cognition. University of Colorado at Boulder.

[7] Stubbs, R. (2011). The sports book. Dorling Kindersley Ltd.

[8] Gori, G. (2004). Italian fascism and the female body: sport, submissive women and strong mothers. Psychology Press.

[9] Tidow, G. (1991). Model technique analysis sheets for the hurdles. Part VII: High hurdles. New Studies in Athletics, 6 (2), 51-66.

[10] López del Amo, J. L., Rodríguez, M. C., Hill, D. W., \& González, J. E. (2018). Analysis of the start to the first hurdle in $110 \mathrm{~m}$ hurdles at the IAAF World Athletics Championships Beijing 2015.

[11] Cureton Jr, T. K. (1939). Elementary principles and techniques of cinematographic analysis as aids in athletic research. Research Quarterly. American Association for Health, Physical Education and Recreation, 10 (2), 3-24.

[12] Sun, D. (2020). Gait analysis and muscoloskeletal modelling used in athletes recovery from Achilles tendon rupture (Doctoral dissertation, Pannon Egyetem).

[13] Cayleff, S. E. (1996). Babe: The Life and Legend of Babe Didrikson Zaharias (Vol. 152). University of Illinois Press.

[14] Radcliffe, J., \& Farentinos, R. (2015). High-Powered Plyometrics, 2E. Human kinetics.

[15] Barber, G. (2006). Getting started in track and field athletics: Advice \& ideas for children, parents, and teachers. Trafford Publishing. 